JIPS, Vol. 2 No. 1 Halaman: 117 - 126 Mei 2021
Jurnal Inovasi Pembelajaran di Sekolah

DOI: https://doi.org/10.51874/jips.v1i01.8

ISSN 2774-9363 (Cetak)

ISSN 2774-9746 (Online)

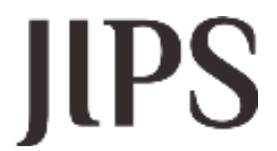

Jurnal Inovasi Pembelajaran di

Sekolah

\title{
Peningkatan Keterampilan Membaca Pemahaman melalui Model Flipped Classroom di SD N 01 Sidomulyo
}

\author{
Eka Setya Septiningrum ${ }^{1}$, Fine Reffiane ${ }^{2}$, dan Karsono ${ }^{3}$ \\ ${ }^{1,2}$ Universitas PGRI Semarang \\ Jl. Sidodadi Timur No.24, Karangtempel, Kec. Semarang Tim., Kota Semarang, Jawa Tengah 50232 \\ ${ }^{3}$ SDIT Supriyadi Semarang \\ Jl. Supriyadi No.7-11, Kalicari, Kec. Pedurungan, Kota Semarang, Jawa Tengah 50198 \\ *E-mail: setyaeka39@student.uns.ac.id, bundafinepgsd@gmail.com, karsonokopen7@gmail.com
}

\begin{abstract}
Abstrak
Tujuan penelitian ini yaitu untuk : (1) meningkatkan hasil belajar pada tema Perkembangan Teknologi melalui model Flipped Classroom, (2) meningkatkan keterampilan membaca pemahaman pada tema Perkembangan Teknologi melalui model Flipped Classroom, (3) meningkatkan aktivitas guru pada tema Perkembangan Teknologi melalui model Flipped Classroom. Penelitian ini merupakan PTK yang direncanakan dan dilaksanakan oleh peneliti sendiri dibantu dengan teman sejawat sebagai observer yang dilaksanakan dalam tiga siklus, setiap siklus terdiri dari perencanaan, pelaksanaan, observasi, dan refleksi. Subjek penelitian ini adalah peserta didik Kelas III A SD N 01 Sidomulyo tahun pelajaran 2020/2021 sebanyak 21 peserta didik. Hasil penelitian ini menunjukkan bahwa: (1) Hasil belajar pada tema Perkembangan Teknologi muatan Bahasa Indonesia dari sisi pengetahuan (KI 3) yang dilihat dari tes hasil belajar yaitu 90,4\% pada siklus 1 dan 2 serta mencapai $100 \%$ pada siklus 3, dari sisi keterampilan (KI 4) yang dilihat dari LKPD muatan Bahasa Indonesia sebanyak 90,4\% pada siklus $1,95,2 \%$ pada siklus 2, serta mencapai $100 \%$ pada siklus 3. (2) Keterampilan membaca pemahaman pada tema Perkembangan Teknologi merujuk pada indikator keterampilan membaca pemahaman yang disampaikan oleh Widasari, M.U (2017: 15) dengan rincian pencapaian indikator pada siklus 1 sebanyak 71,5\%, siklus 2 sebanyak $85,7 \%$, serta mencapai $100 \%$ pada siklus 3. (3) Aktivitas guru menggunakan penerapan model Flipped Classroom diukur menggunakan lembar observasi penerapan model Flipped Classroom diperoleh hasil pada siklus 1 sebanyak 59\%, siklus 2 sebanyak 74\%, serta siklus 3 sebanyak 87,5\%. Kesimpulan penelitian ini adalah penerapan model Flipped Classroom dapat meningkatkan hasil belajar, keterampilan membaca pemahaman, serta aktivitas guru.
\end{abstract}

Kata kunci: Flipped Classroom, Keterampilan Membaca Pemahaman, Hasil Belajar.

\begin{abstract}
The objectives of this study are to: (1) improve learning outcomes on the theme of Technology Development through the Flipped Classroom model, (2) improve reading comprehension skills on the theme of Technology Development through the Flipped Classroom model, (3) increase teacher activity on the theme of Technology Development through the Flipped model. Classroom. This research is a CAR that is planned and carried out by the researchers themselves assisted by colleagues as observers which is carried out in three cycles, each cycle consisting of planning, implementation, observation, and reflection. The subjects of this study were students of Class III A SD N 01 Sidomulyo for the academic year 2020/2021 as many as 21 students. The results of this study indicate that: (1) learning outcomes on the theme of the development of Indonesian language content in terms of knowledge (KI 3) which are seen from the learning outcomes test are 90.4\% in cycles 1 and 2 and reach 100\%
\end{abstract}


in cycle 3, from in terms of skills (KI 4) as seen from the LKPD containing Indonesian as much as $90.4 \%$ in cycle 1, $95.2 \%$ in cycle 2, and reaching 100\% in cycle 3. (2) Reading comprehension skills on the theme of Technological Development refer to indicators of reading comprehension skills presented by Widasari, $M U$ (2017: 15) with details of the achievement of indicators in cycle 1 as much as 71.5\%, cycle 2 as much as $85.7 \%$, and reaching 100\% in cycle 3. (3) Teacher activities using the application of the Flipped Classroom model was measured using an observation sheet on the application of the Flipped Classroom model, the results obtained in cycle 1 were 59\%, cycle 2 was $74 \%$, and cycle 3 was $87.5 \%$. The conclusion of this study is that the application of the Flipped Classroom model can improve learning outcomes, reading comprehension skills, and teacher activities.

Keywords: Describe keywords from your writing from special to public (3-7 words).

\section{PENDAHULUAN}

Pembelajaran di Sekolah Dasar menurut Permendikbud Nomor 57 Tahun 2014 pasal 11 dilaksanakan dengan pendekatan pembelajaran tematik terpadu yaitu muatan pelajaran dalam mata pelajaran SD/MI diorganisasikan ke dalam tema-tema. Seperti dalam penelitian ini yang menggunakan Tema Perkembangan Teknologi pada kelas III, ini berarti dalam tema Perkembangan Teknologi terdapat muatan pelajaran PPKn, Matematika, SBdP, dan Bahasa Indonesia. Bahasa Indonesia yang difokuskan pada tema ini yaitu Teks Bacaan tentang Perkembangan Teknologi, baik Pangan, Sandang, Informasi dan Komunikasi, maupun Transportasi.

Dalam muatan pelajaran Bahasa Indonesia, didalamnya mengharuskan peserta didik menguasai keterampilan membaca pemahaman agar dalam proses pembelajaran peserta didik dapat memahami, mengerti, menafsirkan, menganalisis, dan mengevaluasi isi bacaan (Yasmin, 2018). Adapun indikator membaca pemahaman yang disusun oleh Widasari, M.U (2017:15) antara lain: (1) Siswa dapat membaca teks bacaan dengan benar dan jelas. (2) Siswa dapat menjawab pertanyaan yang berhubungan dengan teks. (3) Siswa dapat menemukan kalimat utama pada setiap paragraf dalam bacaan. (4) Siswa dapat meringkas isi bacaan. (5) Siswa dapat mengartikan kata-kata sukar dalam teks bacaan. (6) Siswa dapat menuliskan informasi dalam bacaan. serta (7) Siswa dapat menjelaskan makna yang terdapat dalam bacaan. Dalam peningkatan keterampilan membaca pemahaman, guru berperan sebagai motor penggerak dalam mendesain pembelajaran sedangkan peserta didik berperan sebagai subyek penelitian dan tokoh utama dalam proses pembelajaran (Kusuma, E.D, 2021: 259). Sedangkan proses pembelajaran yang dimaksud adalah proses pembelajaran yang dapat mengembangkan potensi siswa dengan berbasis aktivitas sehingga siswa berperan secara aktif dalam kegiatan belajar mengajar yang diselenggarakan oleh guru (Azizah, N., Purnomo, D., \& Reffiane, 2018: 330).

Studi awal pelaksanaan pembelajaran di kelas III A SD N 01 Sidomulyo, menemukan fakta bahwa: 1) pembelajaran di era pandemi ini kurang bervariatif, membosankan, dan kurang membuat peserta didik aktif terlibat dalam proses pembelajaran, 2) peserta didik kesulitan mengerjakan lembar kerja peserta didik (LKPD) muatan Bahasa Indonesia karena disana terdapat berbagai teks bacaan yang panjang dan membutuhkan keterampilan membaca pemahaman, 3) guru terlanjur nyaman dengan pembelajaran yang biasanya dilakukan sejak dahulu yaitu ceramah sehingga homevisit ke rumah pesertadidik dengan pengelompokan rumah terdekat pun menjadi jalan utama, 4) peserta didik dan walinya yang sudah hidup berdampingan dengan teknologi namun belum mengetahui cara memanfaatkannya untuk pendidikan secara optimal, khususnya di era pandemi. Berdasarkan permasalahan yang telah diuraikan, maka peneliti memberikan solusi berupa penggunaan model 


\section{Flipped Classroom.}

Model flipped classroom merupakan model yang mana peserta didik diberikan bahan ajar, video pembelajaran ataupun seperangkat pembelajaran yang menarik, disusun oleh peneliti sendiri sehingga peserta didik diharapkan menjadi tertarik dan termotivasi dalam pembelajaran sehingga keterampilan membaca pemahaman meningkat. Muhtadi, A (2019: 117) menyatakan bahwa Flipped Classroom merupakan bagian dari pendekatan blended learning model rotasi yang mana sebelum pembelajaran langsung dimulai peserta didik mendapatkan pengajaran secara langsung melalui video secara online sehingga kelas dimulai peserta didik bisa menyelesaikan tugasnya. Sejalan dengan pendapat yang diungkapkan oleh Zengin, Y (2017) "As a result of the Flipped Classroom, students find more opportunities to get engaged with more activities in class and to have discussions about the concepts involved.". Hal ini menunjukkan bahwa dengan Flipped Classroom, siswa mendapatkan lebih banyak kesempatan untuk terlibat dengan lebih banyak aktivitas dalam pembelajaran dan untuk berdiskusi tentang konsep yang terlibat.

Adapun langkah-langkah model pembelajaran yang peneliti rancang menganut pada pendapat Nofrion (2019:1) yang menyatakan flipped classroom merupakan bentuk dari "blended learning" yang mendesain siswa belajar video pembelajaran di rumah kemudian di kelas mereka berdiskusi bersama dengan guru di kelas. Adapula Bishop, J (2013) yang membagi flipped classroom menjadi empat fase yaitu: melihat video di rumah, mengerjakan tugas di kelas, membuat proyek dan simulasi di kelas, serta evaluasi di akhir. Kemudian langkah flipped classroom ini didesain kembali oleh Suharno (2020:130) yang disesuaikan dengan kondisi pandemi yaitu menjadi 5 tahap: 1) pendahuluan, 2) tahap orientasi dan eksplorasi, 3) interpretasi, 4) rekreasi, serta, 5) penutup dan evaluasi.

Dari berbagai pendapat ahli di atas, peneliti membuat kesimpulan bahwa langkah-langkah model flipped classroom hasil modifikasi dari sistem Belajar Dari Rumah (BDR) dan peneliti yaitu: (1) tahap asinkronus, yang mana peserta didik diberikan stimulus berupa video pembelajaran, modul yang berisi bahan ajar dan LKPD yang dipelajarai terlebih dahulu secara satu arah di rumah masing-masing; (2) tahap sikronus, yang mana langkah ini dilakukan video conference antara guru dengan peserta didik melalui daring, dalam hal ini terjadi komunikasi secara dua arah sehingga miskonsepsi pada tahap asinkronus bisa diluruskan, (3) tahap interpretasi dan rekreasi, yang mana pada tahap ini peserta didika bersama dengan teman dekat, wali peserta didik, orang tua ataupun orang terdekat bekerjasama mengerjakan LKPD yang ditugaskan (4) tahap evaluasi, adalah tahap paling akhir dalam pembelajaran untuk mengetahui sejauhmana ketercapaian hasil belajar peserta didik pada ranah pengetahuan (KI 3).

Hasil penelitian terdahulu yang relevan tentang Flipped Classroom dilakukan oleh Wahyudin, A (2020:22) yang menunjukkan hasil bahwa model tersebut dapat meningkatkan efektifitas pembelajaran serta hasil belajar siswa pada masa pandemi covid-19. Diperkuat oleh penelitian yang dilakukan Kusmaningsih, D (2019:46) yang menyebutkan bahwa model Flipped Classroom dapat meningkatkan hasil belajar dan motivasi siswa. Sejalan dengan penelitian yang dilakukan Suriaman, A dan Dewi AK (2019:76) bahwa pembelajaran Flipped Classroom mampu meningkatkan aktivitas mahasiswa dan juga dosen dalam proses pembelajaran.

Tujuan penelitian ini yaitu, untuk : (1) meningkatkan hasil belajar pada tema Perkembangan Teknologi melalui model Flipped Classroom, (2) meningkatkan keterampilan membaca pemahaman pada tema Perkembangan Teknologi melalui model Flipped Classroom, (3) meningkatkan aktivitas guru pada tema Perkembangan Teknologi melalui model Flipped Classroom. 


\section{METODE PENELITIAN}

Pendekatan penelitian yang digunakan adalah Penelitian Tindakan Kelas (PTK) dengan peneliti sebagai perencang dan pelaksana tindakan dibantu dengan teman sejawat sebagai observer. Subjek penelitian tindakan kelas ini adalah peserta didik kelas III A SD N 01 Sidomulyo tahun pelajaran 2020/2021 yang berjumlah 21 peserta didik, terdiri dari 11 peserta didik laki-laki dan 10 peserta didik perempuan. Selain itu subjek penelitiannya yaitu peneliti sendiri yang bertindak sebagai guru Kelas III A SD N 01 Sidomulyo tahun pelajaran 2020/2021. Penelitian ini terdiri dari tiga siklus, setiap siklus terdiri dari dua pertemuan. Setiap siklus terdapat : 1) perencanaan, 2) pelaksanaan, 3) observasi, serta 4) refleksi. Indikator keberhasilan pada pemelitian ini yaitu sebagai berikut:

Tabel 1. Indikator keberhasilan penelitian

\begin{tabular}{|c|c|c|}
\hline $\begin{array}{l}\text { Aspek yang } \\
\text { Diukur }\end{array}$ & $\begin{array}{l}\text { Persentasi } \\
\text { yang } \\
\text { ditargetkan }\end{array}$ & Cara Mengukur \\
\hline $\begin{array}{l}\text { Hasil Belajar pada tema } \\
\text { Perkembangan } \\
\text { Teknologi }\end{array}$ & $85 \%$ & $\begin{array}{l}\text { Diukur dari penilaian pengetahuan serta } \\
\text { penilaian keterampilan muatan Bahasa } \\
\text { Indonesia dengan minimal nilai } 71 . \\
(\mathrm{KKM}=71)\end{array}$ \\
\hline $\begin{array}{l}\text { Keterampilan membaca } \\
\text { pemahaman peserta didik } \\
\text { pada tema } \\
\text { Perkembangan } \\
\text { Teknologi }\end{array}$ & $85 \%$ & $\begin{array}{l}\text { Diamati saat pembelajaran asinkronus } \\
\text { maupun sinkronus dengan mengunakan } \\
\text { lembar observasi keterampilan membaca } \\
\text { pemahaman }\end{array}$ \\
\hline $\begin{array}{l}\text { Aktivitas guru pada } \\
\text { pembelajaran tema } \\
\text { Perkembangan } \\
\text { Teknologi }\end{array}$ & $85 \%$ & $\begin{array}{l}\text { Diamati saat pembelajaran asinkronus } \\
\text { maupun sinkronus dengan mengunakan } \\
\text { lembar observasi model Flipped } \\
\text { Classrom }\end{array}$ \\
\hline
\end{tabular}

\section{HASIL DAN PEMBAHASAN}

\section{HASIL}

Hasil merupakan bagian utama artikel ilmiah yang berisi : hasil analisis data, hasil pengujian hipotesis, dapat dilengkapi dengan tabel atau grafik, untuk memperjelas hasil secara verbal.

Siklus 1 terdapat tahapan: a) perencanaan, b) pelaksanaan, c) observasi, serta d) refleksi. Kegiatan perencanaan yang dilakukan yaitu: 1) menyiapkan perangkat pembelajaran (silabus, RPP, modul bahan ajar, LKPD, media (PPT dan video), serta perangkat evaluasi; 2) menentukan waktu asikronus dan sikronus dengan peserta didik dan walinya; 3) menyiapkan alat pembelajaran daring serta dokumentasi, 4) berkoordinasi dengan observer; serta 5) melakukan refleksi.

Siklus 2 terdapat tahapan: a) perencanaan, b) pelaksanaan, c) observasi, serta d) refleksi. Dalam tahap pelaksanaan Kegiatan Pembelajaran yang dilakukan yaitu pada Tema 7 (Perkembangan Teknologi) Subtema 3 (Perkembangan Teknologi Komunikasi) Pembelajaran ke-3. Indikator Bahasa Indonesia yang dilaksanakan yaitu : 3.6.5 Menemukan kosakata tentang produk yang dihasilkan teknologi komunikasi (C4), 3.6.6 Menemukan kalimat utama tiap paragraf dari teks bacaan (C4), 4.6.5 Menunjukkan kosakata produk yang dihasilkan teknologi komunikasi (P1), serta 4.6.6 Merangcang ringkasan informasi tentang perkembangan teknologi komunikasi secara tertulis menggunakan kosakata baku dan kalimat efektif (P2).

Tahap asinkronus guru membagikan modul serta video pembelajaran melalui WA Group kelas 
serta menentukan kelompok yang wajib mengikuti tahap sinkronus melalui video conference. Link video pembelajaran peneliti upload di Youtube agar peserta didik serta walinya dapat mengakses dari rumah masing-masing. Untuk modul bahan ajar guru meminta perwakilan wali peserta didik mengambil modul di sekolah. Link video youtube pada pertemuan 2 yaitu : https://youtu.be/FdmdWDqmiQA. Untuk tutorial membuat telepon kaleng dapat dilihat pada link: https://youtu.be/BD3ROB-whgU.

Tahap sinkronus guru memberikan pengumuman pada WA Group tentang peraturan googlemeet serta anggota kelompok yang wajib mengikuti sinkronus pada minggu ini serta menyiapkan link googlemeet. Dokumentasi pertemuan ini dapat dilihat pada link: https://youtu.be/q3ahr4IRmIY. Pada tahap ini guru melakukan sesi pembelajaran penuh mulai dari pendahuluan-inti-penutup. Pendahuluan dibuka dengan salam pembuka, menanyakan kabar peserta didik, menyampaikan tujuan pembelajaran, serta untuk menarik peserta didik guru bercerita tentang alat komunikasi dengan cara kontekstual yang dekat dengan kehidupan peserta didik yaitu kentongan, hp, tablet, dll. Pada kegiatan inti langsung masuk informasi pada teks bacaan dengan memunculkan pertanyaan pemantik "bagaimana cara menemukan informasi?" peserta didik menjawab "menanya" guru memantik pertanyaan kembali kemudian peserta didik menjawab "membaca" kemudian pembelajaran diarahkan untuk membaca teks bacaan berjudul "Sejarah Penggunaan Telepon" secara bergantian peserta didik membaca teks mulai paragraf pertama hingga terakhir. Peserta didik diarahkan untuk membaca panduan mencari kosakata dalam teks bacaan kemudian dialihkan pada LKPD tentang mewarnai kosakata yang berhubungan dengan teknologi komunikasi selanjutnya peserta didik menuliskan kalimat utama dari beberapa paragraf yang selanjutnya disebut dengan ringkasan. Dilanjutkan pada muatan SBdP tentang unsurunsur dekoratif dalam seni rupa dilanjutkan tayangan slide tentang pola hias Jawa Tengah. Berkaitan tentang teknologi komunikasi guru membawakan media telepon kaleng yang dihias deng motif hias Jawa Tengah, peserta diminta membuat produk tersebut. Pembelajaran inti yang paling akhir yaitu muatan Matematika tentang keliling bangun datar, peserta didik terlihat menjawab berbagai pertanyaan tentang keliling bangun datar dengan antusias. Yang menarik pada pertemuan kalia ini yaitu pada sesi penutup ditutup dengan kuis yang mana peserta didik antusias menjawab kuis pertama hingga akhir dan bahkan saling berlomba-lomba dalam menjawab kuis untuk mendapatkan poin. Pembelajaran ditutup dengan doa dan salam penutup.

Tahap Interpretasi dan Rekreasi peserta didik dan bersama partner mempelajari modul, video pembelajaran, dokumentasi sinkronus serta mengerjakan LKPD dengan tepat sesuai dengan jawaban yang diharapkan. Pada tahap ini ada yang menarik yaitu ketika peserta didik secara berpasangan dengan teman satu kelas yang rumahnya dekat membuat telepon kaleng dengan motif hias. Bagi peserta didik ini merupakan tugas produk yang menarik dengan hasil produk yang terlihat pada gambar di bawah ini.

Tahap Evaluasi peserta didik mengerjakan evaluasi yang terdapat pada lembar terakhir modul yang selanjutnya modul dikumpulkan kembali ke sekolah untuk dikoreksi manual oleh guru.

Siklus 3 terdapat tahapan: a) perencanaan, b) pelaksanaan, c) observasi, serta d) refleksi. Pada tahapan observasi 1) Penerapan Model Pembelajaran Flipped Classroom. Peneliti sebagai pelaksana tindakan sekaligus observer yang dibantu teman sejawat mengamati kegiatan pembelajaran menggunakan lembar observasi terhadap guru dan peserta didik. Hasil observasi proses pembelajaran terhadap guru dan peserta didik pada siklus 3 ditampilkan pada tabel 2 . 
Tabel 2. Hasil observasi proses pembelajaran

\begin{tabular}{|c|c|c|c|c|c|c|c|c|}
\hline \multirow{3}{*}{ Langkah } & \multirow{3}{*}{$\begin{array}{c}\text { No. } \\
\text { Indikator }\end{array}$} & \multicolumn{3}{|c|}{ Pertemuan 1} & \multicolumn{3}{|c|}{ Pertemuan 2} & \multirow{3}{*}{$\begin{array}{c}\text { Rata- } \\
\text { rata } \\
\text { Siklus } 3\end{array}$} \\
\hline & & \multicolumn{2}{|l|}{ Observer } & \multirow{2}{*}{$(\%)$} & \multicolumn{2}{|c|}{ Observer } & \multirow{2}{*}{$(\%)$} & \\
\hline & & 1 & 2 & & 1 & 2 & & \\
\hline \multirow{5}{*}{$\begin{array}{l}\text { Tahap } \\
\text { Asinkronus }\end{array}$} & 1 & 3 & 3 & \multirow{5}{*}{88} & 4 & 4 & \multirow{5}{*}{90} & \multirow{5}{*}{$89 \%$} \\
\hline & 2 & 4 & 4 & & 4 & 3 & & \\
\hline & 3 & 3 & 4 & & 4 & 4 & & \\
\hline & 4 & 3 & 4 & & 3 & 4 & & \\
\hline & 5 & 4 & 3 & & 3 & 3 & & \\
\hline \multirow{13}{*}{$\begin{array}{l}\text { Tahap } \\
\text { Sinkronus }\end{array}$} & 6 & 3 & 3 & \multirow{13}{*}{86} & 3 & 3 & \multirow{13}{*}{87} & \multirow{13}{*}{$75 \%$} \\
\hline & 7 & 4 & 3 & & 3 & 3 & & \\
\hline & 8 & 4 & 4 & & 4 & 3 & & \\
\hline & 9 & 3 & 3 & & 3 & 4 & & \\
\hline & 10 & 3 & 4 & & 4 & 3 & & \\
\hline & 11 & 4 & 3 & & 4 & 4 & & \\
\hline & 12 & 3 & 4 & & 4 & 3 & & \\
\hline & 13 & 4 & 3 & & 3 & 4 & & \\
\hline & 14 & 4 & 3 & & 4 & 3 & & \\
\hline & 15 & 3 & 4 & & 4 & 4 & & \\
\hline & 16 & 3 & 3 & & 3 & 3 & & \\
\hline & 17 & 3 & 4 & & 4 & 4 & & \\
\hline & 18 & 3 & 4 & & 3 & 3 & & \\
\hline \multirow{4}{*}{$\begin{array}{l}\text { Tahap } \\
\text { Interpretasi } \\
\text { dan } \\
\text { Rekreasi }\end{array}$} & 19 & 4 & 4 & \multirow{4}{*}{88} & 3 & 3 & \multirow{4}{*}{88} & \multirow{4}{*}{$88 \%$} \\
\hline & 20 & 3 & 3 & & 4 & 4 & & \\
\hline & 21 & 4 & 4 & & 4 & 4 & & \\
\hline & 22 & 3 & 3 & & 3 & 3 & & \\
\hline \multirow{3}{*}{$\begin{array}{l}\text { Tahap } \\
\text { Evaluasi }\end{array}$} & 23 & 4 & 3 & \multirow{3}{*}{88} & 3 & 4 & \multirow{3}{*}{88} & \multirow{3}{*}{$88 \%$} \\
\hline & 24 & 3 & 4 & & 4 & 3 & & \\
\hline & 25 & 4 & 3 & & 3 & 4 & & \\
\hline \multicolumn{2}{|c|}{ Rata-rata } & 2,84 & 2,88 & 87,5 & 3 & 3,04 & 88 & $87,50 \%$ \\
\hline
\end{tabular}

Dari tabel di atas, indikator pencapaian kompetensi tiap langkah model Flipped Classroom yang dilaksanakan oleh guru dan peserta didik mengalami peningkatan mulai dari pertemuan 1 hingga pertemuan 2 sebanyak 1\% dengan rata-rata pencapaian indikator yang dilaksanakan oleh guru dan peserta didik sebanyak 87,5\% yang menurut skala penilaian Arifin (2009: 236) sudah dalam kondisi baik. Sehingga penelitian pun dihentikan pada siklus 3. Sedangkan untuk keterampilan membaca pemahaman peserta didik menggunakan indikator ketrampilan membaca pemahaman yang disampaikan oleh Widasari, M.U (2017: 15) melaui observasi langsung yang dilakukan oleh peneliti sendiri dibantu dengan teman sejawat yang bertindak sebagai observer diperoleh data sebagai berikut:

a. Siswa dapat membaca teks bacaan dengan benar dan jelas ditunjukkan pada pertemuan 1 peserta didik dapat dengan benar dan lancar membaca teks berjudul "Pergi Ke Pulau" serta pada pertemuan 2 yang berjudul "Perjalanan dengan Kereta".

b. Siswa dapat menjawab pertanyaan yang berhubungan dengan teks ditunukkan pada pertemuan 1 maupun 2 ketika guru melayangkan pertanyaan yang berhubungan dengan teks bacaan. 
c. Siswa dapat menemukan kalimat utama pada setiap paragraf dalam bacaan ditunjukkan pada pertemuan 1 dalam pembahasan LKPD tentang menuliskan isi cerita pada bacaan "Pergi ke Pulau".

d. Siswa dapat meringkas isi bacaan ditunjukkan pada pertemuan 1 dalam pembahasan LKPD tentang menuliskan isi cerita pada bacaan "Pergi ke Pulau" secara singkat.

e. Siswa dapat mengartikan kata-kata sukar dalam teks bacaan ditunjukkan pada pertemuan 2 yaitu kosakata yang sulit seperti peron, rel, tiket, dsb.

f. Siswa dapat menuliskan informasi dalam bacaan ditunjukkan ditunjukkan pada pertemuan 1 dalam pembahasan LKPD tentang menuliskan isi cerita pada bacaan "Pergi ke Pulau".

g. Siswa dapat menjelaskan makna yang terdapat dalam bacaan ditunjukkan pada pembahasan LKPD yang membuat kalimat dari kosakata yang berkaitan dengan teknologi trasnportasi.

Hasil Belajar Tema Perkembangan Teknologi yang peneliti fokuskan adalah hasil belajar muatan Bahasa Indonesia dari sisi pengetahuan (KI 3) yang dilihat dari tes hasil belajar/ evaluasi di akhir pembelajaran maupun sisi ketrampilan (KI 4) yang dilihat dari nilai LKPD muatan Bahasa Indonesia. Distribusi frekuensi hasil belajar tema Perkembangan Teknologi pada Siklus 3 terdapat pada tabel berikut :

Tabel 3. Hasil belajar peserta didik

\begin{tabular}{|l|r|r|r|r}
\hline \multirow{2}{*}{ Nilai } & \multicolumn{2}{|c|}{ LKPD (KI 4) } & \multicolumn{2}{c}{ Evaluasi (KI 3) } \\
\cline { 2 - 5 } & \multicolumn{1}{|c}{$\mathrm{F}$} & \multicolumn{1}{c}{$\%)$} & \multicolumn{1}{c}{ f } & $(\%)$ \\
\hline $100-91$ & 16 & 76,2 & 11 & 52.3 \\
\hline $90-81$ & 5 & 23,8 & 4 & 19,2 \\
\hline $80-71$ & 0 & 0 & 6 & 28,5 \\
\hline $70-69$ & 0 & 0 & 0 & 0 \\
\hline$<69$ & 0 & 0 & 0 & 0 \\
\hline Jumlah & 21 & 100 & 21 & 100 \\
\hline Nilai Tertinggi & 100 & - & 100 & - \\
\hline Nilai Terendah & 85 & - & 83 & - \\
\hline Rata-rata & 96 & - & 92 & - \\
\hline Jumlah Siswa Tuntas & $\mathbf{2 1}$ & $\mathbf{1 0 0}$ & $\mathbf{2 1}$ & $\mathbf{1 0 0}$ \\
\hline Jumlah Siswa Belum Tuntas & $\mathbf{0}$ & $\mathbf{0}$ & $\mathbf{0}$ & $\mathbf{0}$ \\
\hline
\end{tabular}

Hasil Belajar pada tema Perkembangan Teknologi yang peneliti gunakan adalah hasil belajar muatan Bahasa Indonesia dari ranah ketrampilan (KI 4) yang diambil dari nilai LKPD maupun ranah pengetahuan (KI 3) yang diambil dari nilai evaluasi muatan Bahasa Indonesia. Dari 21 peserta didik yang mengerjakan penilaian didapatkan nilai rata-rata penilaian ketrampilan 96 dan rata-rata nilai pengetahuan 92 dengan presentase ketuntasan nilai pengetahuan maupun ketrampilan sempurna yaitu $100 \%$. Ini menandakan bahwa indikator kinerja penelitian untuk hasil belajar sudah dalam kategori sangat baik dan meningkat dibanding pada siklus 2 .

\section{PEMBAHASAN}

Berdasarkan pelaksanaan tindakan siklus 1,2, dan 3 diperoleh hasil penelitian: hasil belajar pada tema Perkembangan Teknologi, keterampilan membaca pemahaman, serta aktivitas guru pada tema Perkembangan Teknologi. Berikut hasil penelitiannya.

\section{a. Hasil Belajar pada tema Perkembangan Teknologi}

Hasil belajar tema perkembangan teknologi yang peneliti fokuskan adalah hasil belajar muatan Bahasa Indonesia dari sisi pengetahuan (KI 3) yang dilihat dari tes hasil belajar dan keterampilan (KI 4) yang dilihat dari LKPD muatan Bahasa Indonesia. Perbandingan antar siklus hasil belajar peserta didik yang tuntas dapat dilihat pada grafik berikut: 
Eka Setya Septiningrum, Fine Reffiane, dan Karsono

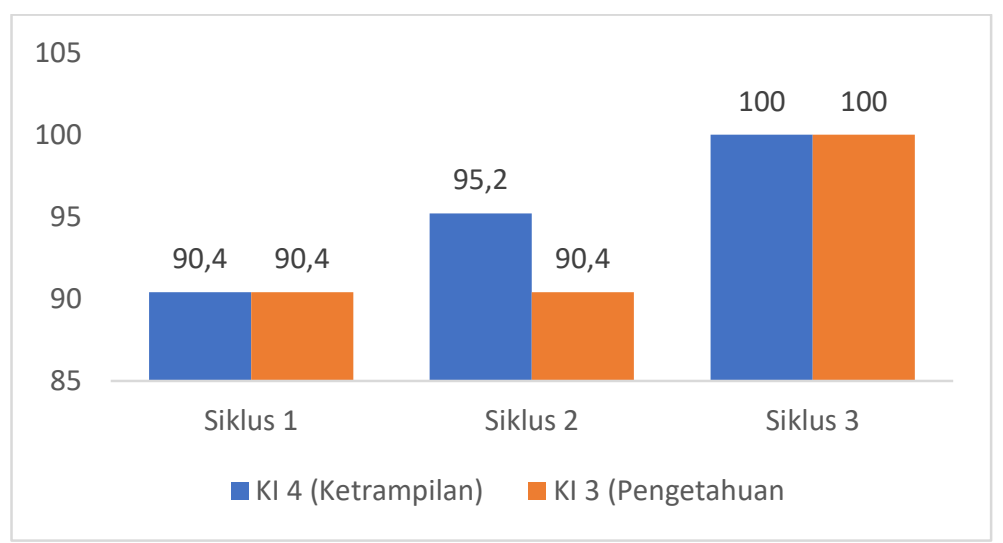

Gambar 1. Diagram perbandingan antar siklus hasil belajar peserta didik yang tuntas

Dari grafik di atas diperoleh data bahwa terjadi peningkatan hasil belajar dalam ranah keterampilan maupun pengetahuan pada Tema Perkembangan Teknologi khususnya muatan Bahasa Indonesia, terlihat pada grafik bahwa hasil belajar keterampilan meningkat 4,8 persen antar siklusnya, sampai pada akhir siklus mencapai 100 persen. Hal ini menunjukkan pada ranah keterampilan sampai siklus 3 seluruh peserta didik sebanyak 21 orang semuanya tuntas. Begitu juga dengan hasil belajar pada ranah pengetahuan yang diambil dari nilai evaluasi muatan Bahasa Indonesia yang stagnan pada jeda siklus 1 dan 2 serta baru mengalami peningkatan pada rentang siklus 2 ke 3 sebanyak 9,6 persen dan mencapai angka 100 persen. Hal ini menunjukkan bahwa sebanyak 21 perserta didik yang menjadi subjek penelitian pada akhir siklus nilai pengetahuan sudah tuntas secara menyeluruh.

\section{b. Keterampilan Membaca Pemahaman Peserta Didik}

Keterampilan membaca pemahaman diamati melalui observasi pada saat pembelajaran asinkron maupun sinkron menggunakan indikator Keterampilan membaca pemahaman yang disampaikan oleh Widasari, M.U (2017: 15) melaui observasi langsung yang dilakukan oleh peneliti sendiri dibantu dengan teman sejawat yang bertindak sebagai observer dengan tujuh indikator yang diharapkan ada, yaitu: dapat membaca teks bacaan dengan benar dan jelas, dapat menjawab pertanyaan yang berhubungan dengan teks, dapat menemukan kalimat utama pada setiap paragraf dalam bacaan, dapat meringkas isi bacaan, dapat mengartikan kata-kata sukar dalam teks bacaan, dapat menuliskan informasi dalam bacaan, serta dapat menjelaskan makna yang terdapat dalam bacaan. sedangkan grafik hasil ketercapaian indikator kinerja penelitian pada ranah Keterampilan membaca pemahaman sebagai berikut:

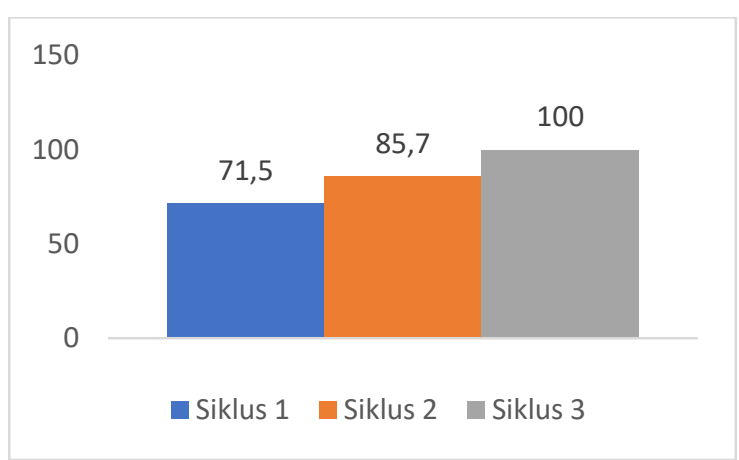

Gambar 2. Grafik hasil ketercapaian indikator kinerja penelitian pada ranah Keterampilan membaca pemahaman 
Dari grafik di atas terbaca jelas bahwa terjadi peningkatan ketrampilan membaca pemahaman sebanyak 14,2 persen serta 14,3 persen yang menjadikan ketercapaian akhir pada siklus 3 mencapai 100 persen. Hal ini menunjukkan bahwa indikator kinerja penelitian yang ditargetkan sebanyak 85 persen sudah terlampaui dengan kategori sangat baik.

\section{c. Aktivitas Guru pada tema Perkembangan Teknologi}

Akitivitas guru pada tema Perkembangan Teknologi dilihat dari observasi penerapan model Flipped Classroom yang dilaksanakan oleh guru dan peserta didik, berikut grafik perbandingan antar siklus peningkatan akivitas guru menggunakan model Flipped Classroom:

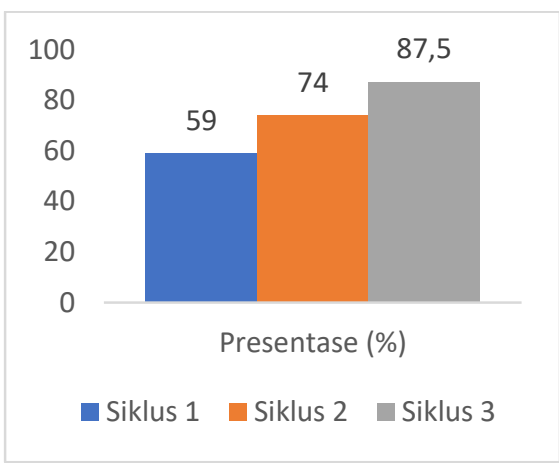

Gambar 3. Grafik perbandingan antar siklus peningkatan akivitas guru menggunakan model

\section{Flipped Classroom}

Berdasarkan grafik yang tertera di atas dapat disimpulkan bahwa terjadi peningkatan aktivitas guru menggunakan model Flipped Classroom mulai dari siklus 1 hingga 3 yaitu terjadi peningkatan sebanyak 15 persen serta 13,5 persen dengan hasil akhir 87,5 persen yang menunjukkan sudah melampaui indikator kinerja penelitian dengan kategori Baik maka penelitian pun dihentikan.

\section{PENUTUP}

Hasil penelitian ini menunjukkan bahwa model Flipped Classroom efektif dapat meningkatkan hasil belajar tema Perkembangan Teknologi khususnya muatan Bahasa Indonesia pada ranah pengetahuan (KI 3) maupun ketrampilan (KI 4), meningkatkan keterampilan membaca pemahaman peserta didik, serta meningkatkan aktivitas guru dalam penerapan model Flipped Classroom pada setiap siklusnya.

\section{UCAPAN TERIMAKASIH}

Terimakasih yang tak terhingga kepada peserta didik kelas III A SD N 01 Sidomulyo yang telah sudi dijadikan subjek penelitian, sehingga penelitian ini dapat berjalan. Segenap wali peserta didik, guru, serta Kepala Sekolah yang telah memberikan dukungan baik moril maupun material sehingga penelitian dapat terlaksana dan berhasil. Segenap Bapak Ibu Dosen Pembimbing serta Guru Pamong (Bu Fine, Pak Aryo, Pak Karsono, Pak Tri), teman-teman seperjuangan PPG Prajabatan UPGRIS, Keluarga tercinta (Ayah, Ibu, Dekmeg, Dekris), serta yang terkasih yang kusemogakan menjadi indah di masa depan (Mas Diart). Terimakasih sudah menjadi motivasi dan penyemangat dalam berjuang. 


\section{DAFTAR PUSTAKA}

Azizah, N., Purnomo, D., \& Reffiane, F. (2018). Pengaruh Model TGT Berbantu Media Utama Terhadap Hasil Belajar Matematika Ditinjau Dari Aktivitas Belajar Siswa Kelas V SD. JS (JURNAL SEKOLAH), 2(4), 329-335.

Bishop, J. (2013). The Flipped Classroom: A Survey Of The Research. Jurnal International Of Utah State University, (June : 2013), 5.

Kusmaningsih, D. (2019). Upaya Meningkatkan Hasil Belajar Siswa Melalui Flipped Classroom Berbasis Youtube Pada Materi Biosfer di Kelas XI IIS 1 SMA N 1 Parongpong. Simpul Juara, 1(1), 2019, 4650.

Kusuma, E.D. (2021). Pengembangan Media Crossword Puzzle Berbasis Hots Pada Pembelajaran Tematik. Jurnal Didaktika Pendidikan Dasar. Vol. 5, No. 1, Maret 2021. doi: 10.26811/didaktika.v5i1.223 EISSN: 2746-0525 P-ISSN: 2580-006X

Muhtadi, A. (2019). Modul 3 Pembelajaran Inovatif. Jakarta: Tim Direktorat Pembinaan GTK PAUD dan Dikmas.

Nofrion. (2019). Flip Your Class Now;Flipped Classroom Melalui Penerapan Model Pembelajaran Exo Olo Task. Dosen Program Studi Pendidikan Geografi.

Permendikbud. (2014). Peraturan Menteri Pendidikan dan Kebudayaan Republik Indonesia Nomor 57 Tahun 2014 Tentang Kurikulum 2013 Sekolah Dasar/Madrasah Ibtidaiyah. Jakarta: Kemendikbud.

Septiningrum, E.S (2021) https://youtu.be/BD3ROB-whgU

Septiningrum, E.S (2021) https://youtu.be/q3ahr4IRmIY

Septiningrum, E.S (2021) https://youtu.be/FdmdWDqmiQA

Suharno. (2020). Penggunaan Model Pembelajaran Flipped Classroom untuk Pembelajaran Daring Sosiologi di Masa Pandemi Covid-19 Kelas XII. IPS SMA Negeri 1 Juwana Kab. Pati tahun 2020. Ijtimaiya : Journal of Social Science Teaching, Vol. 4 No. 2 Tahun 2020 p-issn: 2580-8990

Suriaman, A dan Dewi AK. (2019). Peningkatan Keterampilan Membaca Melalui Flipped Classroom Model. Jurnal Kreatif Online, Vol. 7 No. 4, 2019 ISSN 2354-614X.

Wahyudin, A. (2020). Model Pembelajaran bleended Learning (Model Flipped Classroom) Untuk Meningkatkan Efektivitas Pembelajaran IPS Pada Masa Pandemi Covid19. Journal: Sudut Pandang. Vol. 1 No. 1 (2020): Artikel Penelitian (November).

Widasari, M. U. (2017). Upaya Meningkatkan Kemampuan Membaca Pemahaman Siswa Melalui Metode PQ4R Pada Pelajaran Bahasa Indonesia Dikelas IV MI Islamiyah Sumberrejo Batanghari Lampung Timur Tahun Pelajaran 2016/2017 (Doctoral dissertation, IAIN Metro).

Yasmin, F. (2018). Penerapan Model Pembelajaran Cooperative Integrated Reading and Composition (CIRC) dalam Meningkatkan Hasil Belajar Membaca Pemahaman Siswa. Cokroaminoto Journal of Primary Education 2018. 1(1), 52-57.

Zengin, Y. (2017). Investigating the Use of the Khan Academy and Mathematics Software with a Flipped Classroom Approach in Mathematics Teaching, Journal of Educational Technology \& Society, Vol. 20, No. 2 (April 2017), pp. 89-100 